\title{
KÉTFOKOZATÚ SEBESSÉGVÁLTÓ TERVEZÉSE ALTERNATÍV HAJTÁSÚ JÁRMÜVEKHEZ
}

\author{
Filepkó Máté \\ BSc. géptervezö hallgató, Miskolci Egyetem, Gép-és Terméktervezési Intézet \\ 3515 Miskolc, Miskolc-Egyetemváros, e-mail: filepko.mate@gmail.com \\ Bihari János \\ egyetemi docens, Miskolci Egyetem, Gép-és Terméktervezési Intézet \\ 3515 Miskolc, Miskolc-Egyetemváros, e-mail: machbj@uni-miskolc.hu
}

\begin{abstract}
Absztrakt
Az Aventics Hungary Kft. már tizenkettedik éve rendezte meg a Nemzetközi Aventics Pneumobil versenyt, melynek keretein belül, süritett levegövel hajtott pneumobilok tervezése és épitése a feladat. A versenysorozatban, csapatommal a Miskolci Egyetemet képviselve részt vettünk az idei versenyen is. Pneumobilunk továbbfejlesztésének érdekében, terveztem egy két sebességes orbitális váltót, amely egyszerü, de hatékony megoldás a pneumobil hajtásláncának korszerüsitésére. Ez a váltó kompakt, könnyü és megbizható konstrukció. Ideális egy pneumobil áttételezésére.
\end{abstract}

Kulcsszavak: sebességváltó, pneumobil, fejlesztés

\begin{abstract}
The Aventics Hungary Ltd. has organized the twelfth International Aventics Pneumobile Competition, which includes the design and construction of pneumatic-drive. We participated in this year's competition, with my team at the University of Miskolc. In order to further develop our Pneumobile, I have designed a two-speed orbital gearbox, which is a simple but effective solution for upgrading the pneumatic drive chain. This transmission is a compact, lightweight and reliable construction. Ideal for gearing for a pneumobile.
\end{abstract}

Keywords: gearbox, pneumobil, development

\section{Bevezetés}

A mérnöki tanulmányok során elsajátított elméleti tudást ritkán van lehetőségünk átfogó gyakorlati feladatokkal alaposabban elmélyíteni. Erre ad kiváló lehetőséget ez a versenysorozat, amely minden felsőoktatásban tanuló számára elérhető [3]. Alkalmunk nyílik első kézből megtapasztalni a tervezés és a fejlesztés folyamatát, illetve ötleteinket, terveinket meg is építhetjük, kipróbálhatjuk, láthatjuk müködés közben. Talán ez a mérnöki szakma legszebb része, amikor rengeteg számolás, rajzolás, és gondolkodás után a szerkezet mozgásba lendül, müködik. Az alkotás örömén túl elsajátíthatjuk azt a magatartást és gondolkodásmódot, amellyel egy csoport vagy projekt hasznos tagjaivá válhatunk, ez a tapasztalat pedig később sokat jelenthet, ugyanis a mérnöki munka a leggyakrabban csoportos munkát takar. 


\section{Mi a Pneumobil?}

Pneumatikus jármü, amely a sủrített levegő energiáját alkalmazva, a pneumatikus vezérlő és végrehajtó elemek által kifejtett erőből nyomatékot állít elő a hajtott kerékre vagy kerekekre. Ezek a pneumobilok az Aventics Hungary Kft. által 2008 óta minden évben megrendezett nemzetközi Pneumobil versenyére készülnek, ahol több ország mérnökhallgatói által konstruált jármüvekkel versenyezhetnek. Egyetemünk is rendelkezik több pneumobil csapattal, mely csapatok minden évben képviselik az Alma Matert. Vezetésemmel az AirMEks pneumobil csapat idén 4. alkalommal vett részt a versenysorozatban.

\section{A nyomatékváltók $[1,2]$}

A sebességváltó vagy nyomatékváltó olyan hajtómü, mely a behajtó tengelyen mérhetô nyomatékot és fordulatszámot fokozatonként vagy fokozatmentesen képes megváltoztatni az erőforrás és a hajtott gép lehetőségeinek és igényének megfelelően.

Sebességváltókat különböző célokból használnak. A belsőégésủ motorok gazdaságos teljesítményüket csak viszonylag kis fordulatszám tartományban képesek szolgáltatni. A hajtott gépek (legtöbb esetben gépkocsi, motorkerékpár) fordulatszám- és nyomatékigénye viszont széles határok között változik. Szerszámgépeknél ezzel szemben sokszor van szükség a főmozgás és a mellékmozgások (előtolás) közötti meghatározott áttétel tartására (például, ha esztergagép csavarmenetet vág), ilyenkor a kinematikai kapcsolat pontos tartása fontos, a nyomaték módosítása másodlagos fontosságú. A sebességváltó lehet fogaskerekes, (homlokkerekes vagy bolygómüves), hidrodinamikus vagy hidrosztatikus. Ritkábban használnak szijjhajtású vagy lánchajtású, illetve dörzshajtású sebességváltót.

A belsőégésủ motorok (Otto és dízelmotorok) csak terhelés nélkül indíthatók, álló helyzetben nem üzemképesek, működésükhöz minimális fordulatszámon (üresjárat) kell forogniuk, hogy terhelni lehessen őket. A motor által leadott teljesítmény erősen függ a fordulatszámuktól. A motor teljesítménye, a tengelyén mérhető forgatónyomatéka és fajlagos fogyasztása erősen függ a fordulatszámtól. A szárazföldi kerekes jármüvek hajtása szempontjából előnyös lenne, ha a motor teljesítményét minden sebesség mellett maximálisan ki lehetne használni.

\section{Az orbitális váltó}

Müködési elve: Egy behajtó és egy kihajtó tengelyt tartalmaz, amelyek csapágyazva vannak a váltóházban. A behajtó és a kihajtó tengely is nyeleskerék. Ezek között egy elfordítható konzol helyezkedik el két csapágyazott nyeleskerékkel, amelyek a be- és kihajtó tengellyel állnak kapcsolatban. Ezek áttétele 1:1. Ezeken található egy pár fogaskerék, amelyek az áttételt valósítják meg, úgy, hogy a konzolt $180^{\circ}$-al elfordítva a csapágyazott nyeleskerekeken keresztül, az áttétel reciprok értéke lesz az új áttétel. A váltó tengelykapcsoló nélkül, forgás közben, terhelés alatt is kapcsolható, ha külső egyenes fogazatú fogaskerek valósítják meg benne az erőátvitelt. A váltó fokozatait a konzol elfordításának mértékében az alábbi táblázat foglalja össze. Amint az az 1. táblázatból látszik, a váltót egy irányban körbeforgatva, vagy $180^{\circ}$-on ként oda-vissza forgatva is válthatunk az első és második fokozat között. A váltó rendelkezik üres fokozattal, amely azért fontos, mert a versenyszabályzat értelmében a hátsókereket tudnunk kell függetleníteni a hajtáslánctól. Mi ezt a váltóval valósítjuk meg. 
Az ötlet egy Lego makettből származik, melyet csapatunk felkészítő tanára talált és mutatott meg. A müködési elv átültetése, és a tervezés a pneumobil igénybevételeihez igazodva, a kis tömeget és beépítési méretet is szem előtt tartva, rendkívül bonyolult mérnöki feladatnak bizonyult.

\begin{tabular}{|c|c|}
\hline Fokozat & Elfordítás \\
\hline 1. fokozat & $0^{\circ}$ \\
\hline üres fokozat & $90^{\circ}$ \\
\hline 2. fokozat & $180^{\circ}$ \\
\hline üres fokozat & $270^{\circ}$ \\
\hline 1. fokozat & $360^{\circ}$ \\
\hline
\end{tabular}

1. táblázat

\subsection{A váltó és a központi tag képe}

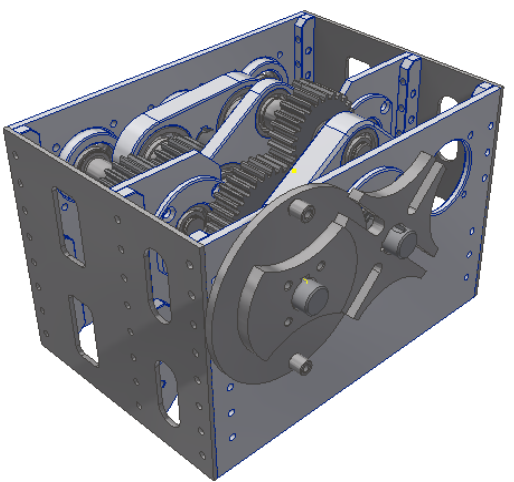

1. ábra

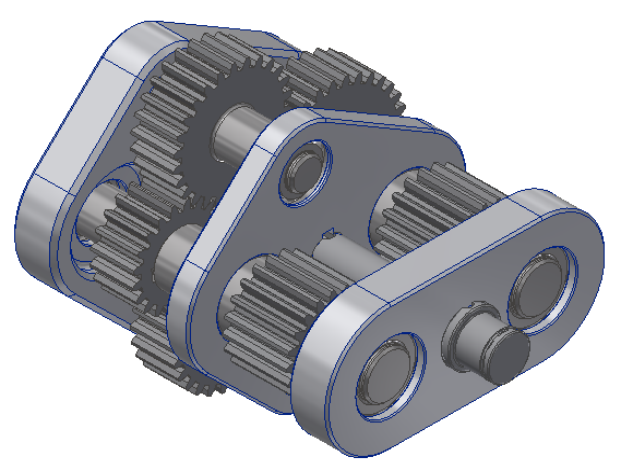

2. ábra

\subsection{A központi tag}

A központi tagban (2. és 4. ábra) található nyeleskerekek a fordítókonzolokon vannak csapágyazva, így szabadon el tudnak fordulni bennük. A két fordítócsap viszont reteszelve van, a második csap elfordításával az egész központi tag elfordítható, ezzel megvalósítva a váltást.

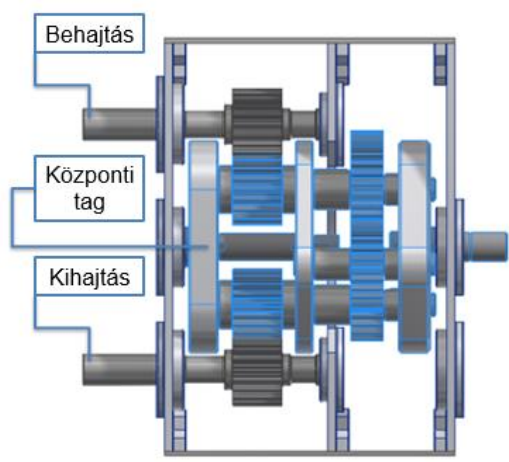

3. ábra

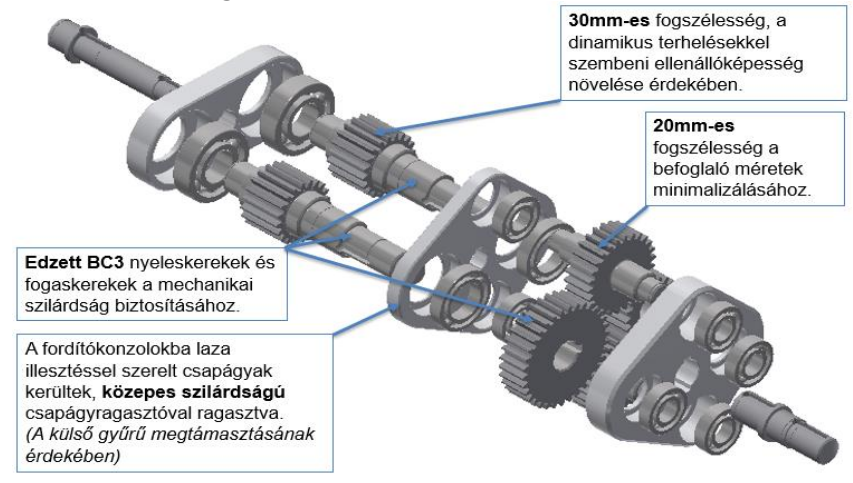

4. ábra 


\section{A váltóház}

A váltóház (5. ábra) falai alumíniumból készülnek, melyeket alumínium konzolokkal rögzítünk az acél elö és hátlaphoz. A csapágyak az alumínium csapágyházakban kapnak helyet. Ezzel tovább csökkentve az össztömeget.

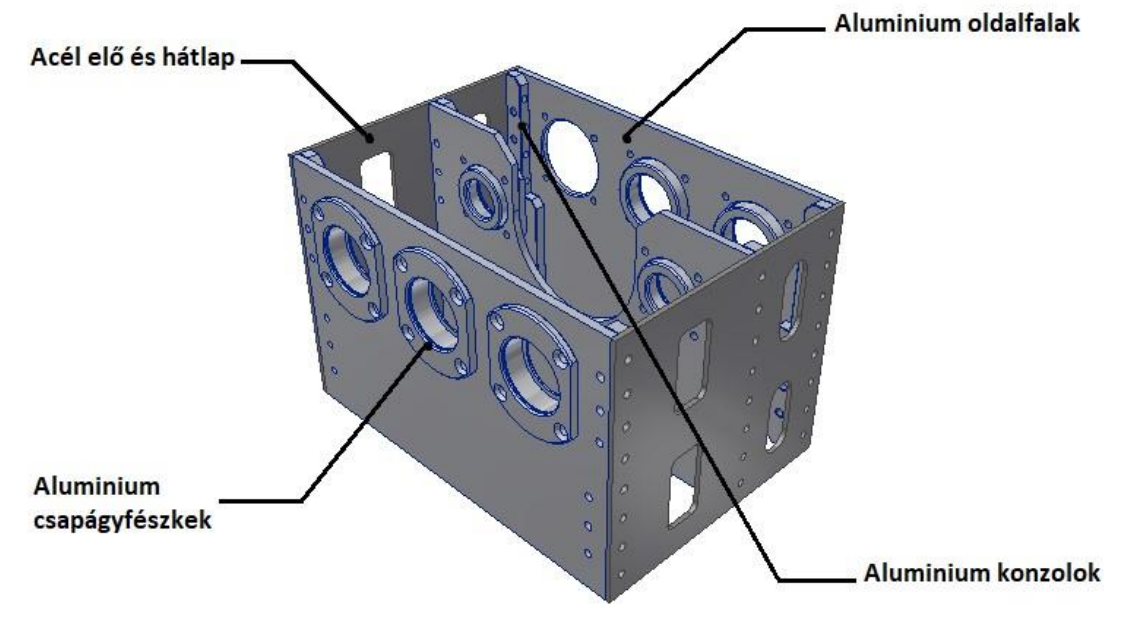

5. ábra

\section{A forgatómechanizmus}

A csap és vele a konzol elfordítására egy máltaikereszt-mechanizmust alkalmaztunk. A máltaikereszthajtás egy mechanizmus, mely folytonos körmozgást megszakított körmozgássá alakít. Nevét arról kapta, hogy az egyik eleme egy máltai kereszt geometriájára hasonlít. Ez a megszakításos hajtómü egy hajtó tárcsából áll (2), melyen egy, vagy több excentrikus csap (1) helyezkedik el. Ez a csap a máltai kereszt alakú alkatész (3) hornyában csúszva addig forgatja az alkatrészt, míg ki nem lép belőle, ezután a tárcsa tovább forog, de nem mozgatja a máltai keresztet addig, amíg el nem éri a következő hornyot, melyben csúszva ismét egy meghatározott szöggel fordítja el, és így tovább.

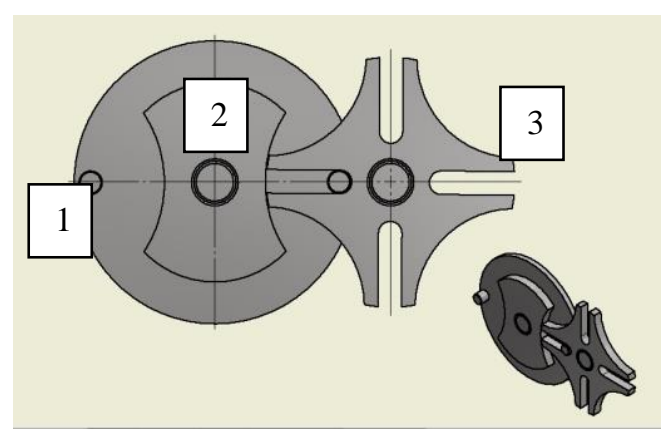

6. ábra

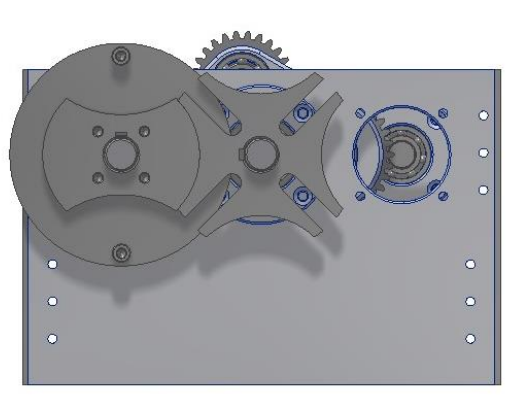

7. ábra

A tárcsán még egy körcikk alakú kiemelkedés is található, melynek az a feladata, hogy a máltai kereszt szintén körcikk alakú kontúrjába illeszkedve megakadályozza annak elfordulását addig, míg a 
csap el nem éri a következő hornyot. Ezzel reteszeli az adott pozíciót, a mi esetünkben a sebességi fokozatot. Ez a mechanizmus egyszerre látja el a diszkrét szögelfordítás, és a sebességi fokozatok, fordítások közötti rögzítő funkciót is. Kompakt és megbízható megoldást biztosít a forgatásra és a reteszelésre egyaránt.

\section{7. Összefoglalás}

A versenyen szereplő csapatok közül kevés rendelkezik sebességváltóval, mivel a kerékpárokon használt váltók és agyváltók nem bírják el a teherbírásukhoz képest megnövekedett tömeget és terhelést, más, kereskedelemben megvásárolható váltók pedig kevésbé igazodnak a pneumobilok igényeihez (ezek: alacsony fordulatszám, nagy nyomaték, kis beépítési méret, alacsony tömeg), vagy túl bonyolultak, vagy túl nehezek ahhoz, hogy egy pneumobilra felszerelve jó hatásfokkal üzemeljenek.

Ezen okokból kifolyólag döntöttünk úgy, hogy egy egyedi váltót tervezek és ezt építjük be a pneumobilunk hajtásláncába. Az egyedi tervezés lehetővé tette, hogy igényeinknek megfelelő sebességváltó kerüljön a jármüre.

Ugyanakkor figyelembe kellett vennem, mind a tervezés mind a kivitelezés során, hogy csapatunk erőforrásai és az egyedi alkatrészek gyártásának lehetőségei korlátozottak, így törekedtem az egyszerü és olcsó, így a rendelkezésre álló forrásokból is megvalósítható konstrukcióra.

\section{Köszönetnyilvánítás}

A cikkben ismertetett kutató munka az EFOP-3.6.1-16-2016-00011 jelü „Fiatalodó és Megújuló Egyetem - Innovativ Tudásváros - a Miskolci Egyetem intelligens szakosodást szolgáló intézményi fejlesztése" projekt részeként - a Széchenyi 2020 keretében - az Európai Unió támogatásával, az Európai Szociális Alap társfinanszírozásával valósul meg.

\section{Irodalom}

[1] Zinner, Gy. Gépjármüvek eröátviteli berendezései, Tankönyvmester Kiadó 2008 ISBN: 9639668222

[2] https://hu.wikipedia.org/wiki/Sebess\%C3\%A9gv\%C3\%A1lt\%C3\%B3

[3] Bihari, J. Pneumobile competition and education, Advanced Engineering 2012, 2(1):125-134. 